\title{
Glycerol utilization in Fusarium oxysporum var. lini: regulation of transport and metabolism
}

\author{
Ieso M. Castro $\dagger$ and Maria C. Loureiro-Dias* \\ Laboratory of Microbiology, Gulbenkian Institute of Science, Oeiras, Portugal \\ (Received 30 November 1990; revised 7 February 1991; accepted 12 March 1991)
}

\begin{abstract}
Glycerol was transported in the fungus Fusarium oxysporum var. lini by a facilitated diffusion transport system with a half-saturation constant, $K_{\mathrm{s}}$, of $0.5 \mathrm{mM}$ and a maximum velocity, $V_{\max }, 0$ o. $0.9 \mathrm{mmol}(\mathrm{g} \mathrm{dry} \mathrm{wt})^{-1} \mathrm{~h}^{-1}$ at pH 5 and $25^{\circ} \mathrm{C}$. 1,2-Propanediol was a competitive inhibitor of glycerol transport, but the cells did not actively accumulate 1,2-propanediol. The transport system was partially constitutive. In cells grown in the presence of glucose, glycerol was not transported, indicating that the synthesis of the system was under glucose repression. Glycerol kinase and NADP+-dependent glycerol dehydrogenase activities were present under all physiological conditions tested. A flavin-dependent glycerol phosphate dehydrogenase was induced only when glycerol was the sole energy source in the medium. This enzyme, together with the transport system, constitute the regulated steps in the glycerol metabolic pathway.
\end{abstract}

\section{Introduction}

The utilization of nutrients by micro-organisms involves an initial uptake step and subsequent metabolism. In the case of glycerol, although metabolism has been quite extensively studied in several cases, transport has been characterized only for Escherichia coli, in which the existence of a glycerol facilitator was first reported by Sanno et al. (1968). A report on the cloning of the gene $(g l p F)$ which codes for this facilitator in $E$. coli was recently published by Sweet et al. (1990). Metabolism of glycerol in E. coli involves an initial phosphorylation step by a glycerol kinase (EC 2.7.1.30), which may take place either inside or outside the inner membrane (Koch et al., 1964), and a subsequent dehydrogenation step by glycerol-3-phosphate dehydrogenases (EC 1.1.2.1) (Koch et al., 1964; Kistler et al., 1969; Kistler \& Lin, 1972).

For eukaryotic micro-organisms two main routes for glycerol metabolism have been identified. In the first route, discovered in the yeasts Saccharomyces cerevisiae and Candida utilis, glycerol is first phosphorylated and subsequently dehydrogenated. The performances of the two yeast species were compared by Gancedo et al.

† Present address: Departamento de Farmácia, Escola de Farmácia, Universidade Federal de Ouro Preto, 35400 Ouro Preto, Minas Gerais, Brazil.

Abbreviation: CCCP, carbonyl cyanide $m$-chlorophenylhydrazone.
(1968), who showed that $C$. utilis could metabolize glycerol much faster than $S$. cerevisiae. The authors did not find enough evidence for the existence of a glycerol transporter in C. utilis and proposed that the plasma membrane of this yeast was much more permeable to glycerol than that of $S$. cerevisiae. In $C$. utilis glycerol 3-phosphate is dehydrogenated in the mitochondria by a flavin-dependent glycerophosphate oxidase (EC 1.1.99.5) (Gancedo et al., 1968).

In the second metabolic route found in yeasts, glycerol is first oxidized by a NAD ${ }^{+}$-dependent dehydrogenase to dihydroxyacetone which is subsequently phosphorylated. This mechanism was described for Schizosaccharomyces pombe (May \& Sloan, 1981; Kong et al., 1985; Gancedo et al., 1986) and Candida valida (Gartner \& Kopperschlager, 1984).

There have been a number of studies on glycerol metabolism in filamentous fungi (for a review see Jennings, 1984). In Aspergillus niger a metabolic pathway involving glycerol phosphorylation prior to glycerol phosphate dehydrogenation was reported by Witteveen et al. (1990). The existence of a carrier-mediated transport system for glycerol was postulated for $\boldsymbol{A}$. nidulans after characterization of $g l c C$ mutants in which no internal glycerol could be detected after incubation of the cells in a medium containing glycerol, in contrast to observations on wild-type strains (Visser et al., 1988). For Neurospora crassa the main metabolic pathway also involves phosphorylation of glycerol prior to dehydroge- 
nation (Courtright, 1975; Denor \& Courtright, 1978). Both enzymes were shown to be inducible and their synthesis was repressed by glucose (Courtright, 1975). A recent genetic analysis revealed a new type of mutant $\left(G l p^{-}\right)$, in which a putative glycerol transporter was proposed to be missing (Denor \& Courtright, 1982).

Glycerol plays a prominent role in osmoregulation in the yeast Debaryomyces hansenii (Nobre \& Costa, 1985; Adler et al., 1985; Andre et al., 1988). A cotransport system for $\mathrm{Na}^{+}$and glycerol that is involved in osmoregulation in this yeast was described by Lucas et al. (1990). Evidence was presented that the concentration gradients of glycerol and $\mathrm{Na}^{+}$are linked through the $\mathrm{Na}^{+} /$glycerol symport, using the $\mathrm{Na}^{+}$gradient as a driving force for maintaining the glycerol gradient across the plasma membrane.

In this work we present data on the transport and metabolism of glycerol in Fusarium oxysporum var. lini under different growth conditions. Glycerol is a main constituent of ethanol distillery waste in Brazil, where this waste constitutes a serious pollution problem. $F$. oxysporum is being utilized tentatively in the processing of the waste for the production of microbial protein. Studies on growth of $F$. oxysporum on glycerol indicate that the synthesis of a glycerol transport system is a regulatory step in the utilization of this polyol by the fungus. To our knowledge this is the first time that a transport system for glycerol, used in its dissimilation, has been characterized in a eukaryotic micro-organism.

\section{Methods}

Organism and growth conditions. Fusarium oxysporum var. lini ATCC 10960 was maintained on potato dextrose agar at $4{ }^{\circ} \mathrm{C}$ after growth for $7 \mathrm{~d}$ at $30^{\circ} \mathrm{C}$. The fungus was grown in a medium containing $1 \%(w / v)$ peptone, $0.2 \%$ yeast extract, $0.5 \% \quad \mathrm{KH}_{2} \mathrm{PO}_{4}$ and $0.075 \%$ $\mathrm{MgSO}_{4} \cdot 7 \mathrm{H}_{2} \mathrm{O}$. Carbon sources (glycerol, ethanol, glucose) were added at a concentration of $2 \%(w / v)$. For growth $200 \mathrm{ml}$ of appropriate medium were used in 1 litre shake flasks in an orbital incubator at $25^{\circ} \mathrm{C}$. Cells were harvested in mid-exponential phase by centrifugation at $20000 \mathrm{~g}$ and washed three times with ice-cold water for transport measurements. For enzyme assays, cells were harvested by filtration and washed on the filter.

Measurement of glycerol uptake rates. The initial uptake rate of $\left[2-{ }^{3} \mathrm{H}\right] \mathrm{glycerol}$ was measured as previously described (Loureiro-Dias \& Peinado, 1984). Cell suspension $(20 \mu \mathrm{l}$; about $0.5 \mathrm{mg}$ dry wt), $20 \mu \mathrm{T} \mathrm{Tris} /$ citrate buffer $(\mathrm{pH} 5 \cdot 0,100 \mathrm{mM})$ and $10 \mu \mathrm{l}$ of a solution of $\left[2-{ }^{3} \mathrm{H}\right]$ glycerol were incubated at $26^{\circ} \mathrm{C}$ for $10 \mathrm{~s}$ (the range of final concentrations of glycerol was 0.02 to $20 \mathrm{~mm}$ and the specific activity was about $90 \mathrm{GBk} \mathrm{mol}^{-1}$ ). Incorporation was stopped by the addition of $5 \mathrm{ml}$ of ice-cold water. Cells were filtered immediately and washed on GF/C Whatman glass-fibre filters and radioactivity was counted in a liquid scintillation system. Controls were prepared by the addition of $5 \mathrm{ml}$ of cold water prior to the addition of labelled glycerol. To check that the measurements were good estimates of initial uptake rates, the linearity of incorporation with time was confirmed for periods up to $20 \mathrm{~s}$. All assays were done in duplicate. $\left[2-{ }^{3} \mathrm{H}\right]$ Glycerol was from Amersham.
Measurement of intracellular volume. The intracellular volume was determined using ${ }^{60} \mathrm{Co}$-EDTA as an extracellular marker (Ferreira \& Swensson, 1979). Cell suspension ( $2 \mathrm{ml} ; 20 \mathrm{mg}$ dry wt) was mixed with $4 \mathrm{ml}$ potassium phosphate buffer (100 mM, pH 5), $60 \mu \mathrm{l} 10 \mathrm{~mm}-\mathrm{CoCl}_{2}$, $60 \mu \mathrm{l} 100 \mathrm{~mm}$-EDTA and $100 \mu \mathrm{l}{ }^{60} \mathrm{CoCl}_{2}(3 \mathrm{kBq})$. Samples $(5 \mathrm{ml})$ were filtered on $0.45 \mu \mathrm{m}$ Sartorius membranes. Pellets were removed with a spatula into tared Eppendorf tubes and counted for $10 \mathrm{~min}$ in a $\gamma$ counter. As a reference, $120 \mu \mathrm{l}$ of supernatant was used. Parallel samples were prepared for measuring the amount of fungal material present in each assay. The water volume was taken as the difference between wet and dry weight. External volume was derived from the ratio between counts in the pellet and in the supernatant. Intraceliular volume was calculated as the difference between water and external volumes. A value of $2 \cdot 16 \pm 0 \cdot 22(n=8) \mu \mathrm{l}(\mathrm{mg} \mathrm{dry} \mathrm{wt})^{-1}$ was obtained.

Accumulation ratio of 1,2-propanediol. The ability of cells grown on glycerol and on glucose to accumulate 1,2-propanediol was investigated by measuring the external concentration of 1,2-propanediol in a thick suspension of cells and calculating the internal concentration taking into account the value for internal volume measured above. The accumulation ratio was calculated as the ratio between intracellular and external concentrations. Cells were filtered and the pellet $(1 \mathrm{~g}$ wet wt) was suspended in $5 \mathrm{ml} 1 \mathrm{~mm}$-1,2-propanediol in potassium phosphate buffer $(100 \mathrm{mM}, \mathrm{pH} 5)$ in a beaker at $26^{\circ} \mathrm{C}$. The suspension was manually stirred with a glass rod and filtered through a GF/C Whatman filter after $10 \mathrm{~min}$; the filtrate was then harvested for subsequent analysis. The concentration of 1,2-propanediol in filtrates was determined according to the method described by Jones \& Riddick (1957). A $1 \mathrm{ml}$ volume of the sample was mixed with $5 \mathrm{ml}$ concentrated sulphuric acid, kept at $70^{\circ} \mathrm{C}$ for $10 \mathrm{~min}$ and cooled to room temperature. Ninhydrin reagent $(0.2 \mathrm{ml} ; 3 \%, \mathrm{w} / \mathrm{v})$ solution in $5 \%(\mathrm{w} / \mathrm{v})$ aqueous $\mathrm{NaHSO}_{3}$ ) was added and the mixture was allowed to stand for $1 \mathrm{~h}$ at $25^{\circ} \mathrm{C}$. The mixture was then diluted to $12.5 \mathrm{ml}$ with concentrated sulphuric acid and the optical density was read at $595 \mathrm{~nm}$ after allowing the colour to develop for $10 \mathrm{~min}$. A calibration curve was prepared in the concentration range 5 to $50 \mu \mathrm{g} \mathrm{ml}^{-1}$. Where indicated (see Results) $50 \mu \mathrm{M}$-CCCP or $30 \mathrm{~mm}$-glycerol were added.

Inactivation of the glycerol transport system by glucose. A culture growing exponentially on glycerol was divided into aliquots to which glucose was added in the concentration range 10 to $300 \mathrm{~mm}$. Incubations were done as described above under growth conditions. At various times cells were harvested by filtration, washed and the initial uptake rate of $5 \mathrm{~mm}$-glycerol was measured as described above. The reversibility of the effect of glucose was tested in cells that had been inactivated by $100 \mathrm{~mm}$-glucose by filtering, washing, suspending in $100 \mathrm{~mm}$-Tris/citrate buffer at the original density and measuring glycerol uptake after incubation for periods of 10 and $20 \mathrm{~min}$.

Monitoring $\mathrm{H}^{+}$-uptake. Changes in the $\mathrm{pH}$ value of unbuffered suspensions of glycerol-grown cells upon addition of glycerol were monitored as described previously (Loureiro-Dias \& Peinado, 1984).

Glycerol and glucose concentrations. Glycerol and glucose concentrations in culture media were estimated enzymically using Boehringer Biochemica Test Combinations for neutral fat and glycerol and for glucose, respectively. Samples were prepared by centrifugation.

Preparation of cell-free extracts. Fresh cells were frozen at $-20^{\circ} \mathrm{C}$ and about $0.3 \mathrm{~g}$ (wet wt) was transferred into $10 \mathrm{ml}$ tubes. After addition of $0.5 \mathrm{ml}$ of the appropriate buffer (containing $1 \mathrm{mM}$ dithiothreitol and $1.2 \mathrm{~g} 0.5 \mathrm{~mm}$ diam. glass beads), extracts were obtained by vigorous shaking for four periods of $1 \mathrm{~min}$ on a laboratory tube shaker (Vortex Junior) with 1 min intervals between shaking steps (Funayama et al., 1980). During these intervals the tubes were placed on ice. After addition of $1 \mathrm{ml}$ of buffer, cell homogenates were transferred to micro test-tubes, and centrifuged in an Eppendorf 5414 
centrifuge at 6000 r.p.m. for 2 periods of $4 \mathrm{~min}$. The supernatants were used for enzyme assays.

Enzyme assays and protein determination. The activities of enzymes were assayed at $30^{\circ} \mathrm{C}$ in a Perkin-Elmer spectrophotometer model 552 connected to a Perkin-Elmer absorbance recording system model 561. Except for glycerol phosphate oxidase, enzyme activities were monitored at $340 \mathrm{~nm}$ to follow changes in the concentration of NADH or NADPH occurring directly in the reaction mixture or by coupling the reaction to an auxiliary enzyme system. Glycerol kinase (EC 2.7.1.30) activity was assayed as described by Gancedo $e t$ al. (1968) by following ADP formation in a system containing $50 \mathrm{~mm}-$ Tris/HCl buffer, pH 7.6, $10 \mathrm{~mm}-\mathrm{MgCl}_{2}, 1 \mathrm{mM}-\mathrm{ATP}, 1 \mathrm{mM}$-phosphoenolpyruvate, $0.2 \mathrm{~mm}-\mathrm{NADH}$ and 1 unit of pyruvate kinase and lactate dehydrogenase $\mathrm{ml}^{-1}$. The reaction was started by addition of $0.1 \mathrm{~mm}-$ glycerol. The rate of NADH oxidation prior to substrate addition was taken as the control. Glycerophosphate oxidase (EC 1.1.99.6) activity was measured at $420 \mathrm{~nm}$ using ferricyanide as an electron acceptor (Dawson \& Thorne, 1975) in a reaction system containing $25 \mathrm{~mm}$ potassium phosphate buffer, $\mathrm{pH} 7 \cdot 6$, and $1 \mathrm{mM}$-potassium ferricyanide. The reaction was started by addition of $70 \mathrm{mM}-\mathrm{DL}-3$-glycerophosphate, after monitoring endogenous reduction of ferricyanide for $3 \mathrm{~min}$.

Glycerol-3-phosphate dehydrogenase (EC 1.1.1.8) was measured in a reaction system containing $50 \mathrm{~mm}$-imidazole $/ \mathrm{HCl}, \mathrm{pH} 7.0,0.2 \mathrm{~mm}$ NADH and $10 \mathrm{~mm}$-EDTA. The reaction was started by the addition of 0.1 mM-dihydroxyacetone phosphate (Gancedo et al., 1968). Glycerol dehydrogenase (glycerol : $\mathrm{NADP}^{+}$oxidoreductase; EC 1.1.1.72) activity was measured in a reaction system containing $50 \mathrm{mM}$-potassium

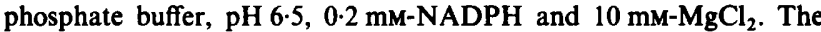
reaction was started by the addition of $0.1 \mathrm{mM}$-DL-glyceraldehyde (Flynn \& Cromlish, 1982). Glycerol dehydrogenase (glycerol : NAD ${ }^{+}-2-$ oxidoreductase; EC 1.1.1.6) activity was measured in a reaction

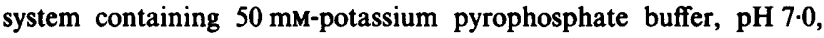
$10 \mathrm{mM}-\mathrm{MgCl}_{2}$, and $0.2 \mathrm{mM}-\mathrm{NADH}$. The reaction was started by the addition of $0 \cdot 1 \mathrm{~mm}$-dihydroxyacetone (Burton, 1955).

Enzyme activities, expressed as international units, were calculated by the use of the following absorption coefficients: $6.22 \mathrm{mM}^{-1} \mathrm{~cm}^{-1}$ for NADH and $1.04 \mathrm{~mm}^{-1} \mathrm{~cm}^{-1}$ for ferricyanide. Protein in crude extracts was estimated by the method of Bradford (1976) at $495 \mathrm{~nm}$, using bovine serum albumin as a standard.

Chemicals and enzymes. Enzymes and substrates were obtained from Sigma. Other reagents were all of analytical grade.

\section{Results}

\section{Growth on glycerol}

F. oxysporum var. lini was able to grow on glycerol at $25^{\circ} \mathrm{C}$ with a specific growth rate of $0.14 \mathrm{~h}^{-1}$ and a yield coefficient of $44 \%$ as compared with values of $0.16 \mathrm{~h}^{-1}$ and $56 \%$ for growth on glucose under the same conditions. In culture medium with glycerol plus glucose the fungus exhibited diauxic growth, i.e. two exponential growth phases, with glycerol being utilized only after glucose had been exhausted.

\section{Glycerol transport}

The kinetics of initial uptake of $\left[{ }^{3} \mathrm{H}\right]$ glycerol was investigated in glycerol-grown cells over the concentration range 0.02 to $20 \mathrm{~mm}$. The results indicated that
Table 1. 1,2-Propanediol accumulation ratios in cells of $F$. oxysporum var. lini grown on glycerol and on glucose

Cells were incubated with $1 \mathrm{mM}-1,2$-propanediol and the accumulation ratio was calculated from the change in external concentration after $10 \mathrm{~min}$, using a value of $2.16 \mu \mathrm{l}(\mathrm{mg} \mathrm{dry} \mathrm{wt})^{-1}$ for intracellular volume.

\begin{tabular}{llc}
\hline \hline $\begin{array}{c}\text { Growth } \\
\text { substrate }\end{array}$ & \multicolumn{1}{c}{ Treatment } & $\begin{array}{c}\text { Accumulation } \\
\text { ratio }\end{array}$ \\
\hline Glycerol & \multicolumn{1}{c}{-} & $2 \cdot 1$ \\
& $+50 \mu \mathrm{M}$-CCCP added at time zero & $2 \cdot 5$ \\
& $+30 \mathrm{mM}$-glycerol added after & $2 \cdot 3$ \\
& $10 \mathrm{~min}$; incubation proceeded for a \\
& further 3 min & \\
Glucose & & 1.9 \\
& $+50 \mu \mathrm{M}-\mathrm{CCCP}$ added at time zero & 1.0 \\
& $+30 \mathrm{mM}$-glycerol added after 10 & 1.5 \\
& min; incubation proceeded for a & \\
& further 3 min \\
\hline \hline
\end{tabular}

glycerol transport followed saturation kinetics. At $\mathrm{pH} 5$ and $25^{\circ} \mathrm{C}$ the half-saturation constant $\left(K_{\mathrm{s}}\right)$ was $0.48 \pm$ $0.25 \mathrm{mM}(n=5)$ and the maximum velocity $\left(V_{\max }\right)$ was $0.87 \pm 0.25 \mathrm{mmol}(\mathrm{g} \text { dry wt })^{-1} \mathrm{~h}^{-1}(n=5)$. A number of related compounds were tried as possible competitive inhibitors of glycerol transport (1,2-propanediol, 1,3propanediol, erythritol, glyceraldehyde, ethylene glycol, dihydroxyacetone and ethanol). Only 1,2-propanediol affected glycerol transport in a competitive way $\left(K_{\mathrm{i}}=\right.$ $22 \mathrm{mM}$; results not shown). In order to elucidate the nature of the glycerol transport system, we investigated whether there was any movement of $\mathrm{H}^{+}$upon addition of glycerol to unbuffered cell suspensions of glycerol-grown cells, in order to check whether a $\mathrm{H}^{+} /$glycerol symporter was involved. However, no external alkalinization was observed. Also, the ability of the cells to accumulate a nonmetabolizable analogue (which would be an indication of active transport) was examined. The accumulation ratio of 1,2-propanediol was evaluated for cells grown on glycerol and on glucose. Results are summarized in Table 1. Addition of $50 \mu \mathrm{M}-\mathrm{CCCP}$ had no effect and $30 \mathrm{mM}$ glycerol did not induce outflow of 1,2 propanediol. The results suggest that in $F$. oxysporum var. lini glycerol is transported by a facilitated diffusion system, since results were similar for glycerol- and glucose-grown cells.

\section{Regulation of glycerol transport}

Initial rates of glycerol uptake were measured in cells grown under different physiological conditions in order to study regulation. Glucose-grown cells did not transport glycerol at all. This observation indicates that the cytoplasmic membrane is impermeable to glycerol and is in good agreement with the result stated above concerning the kinetics of glycerol transport in glycerol-grown 
Table 2. Activities of enzymes involved in glycerol metabolism in F. oxysporum var. lini in cells grown on different carbon sources

\begin{tabular}{lccc}
\hline \hline $\begin{array}{c}\text { Carbon } \\
\text { source }\end{array}$ & $\begin{array}{c}\text { Glycerol } \\
\text { kinase }\end{array}$ & $\begin{array}{c}\text { Glycerol } \\
\text { phosphate } \\
\text { oxidase }\end{array}$ & $\begin{array}{c}\text { Glycerol } \\
\text { dehydrogenase } \\
\text { (NADP }\end{array}$ \\
\hline $\begin{array}{l}\text { Glycerol } \\
\text { Glycerol }+\end{array}$ & $88 \pm 62(n=34)$ & $47 \pm 27(n=15)$ & $52 \pm 10(n=10)$ \\
$\begin{array}{l}\text { glucose } \\
\text { Glucose }\end{array}$ & $78 \pm 50(n=17)$ & 0 & $26 \pm 8(n=10)$ \\
Ethanol & $98 \pm 68(n=17)$ & 0 & $28 \pm 12(n=10)$ \\
\hline \hline
\end{tabular}

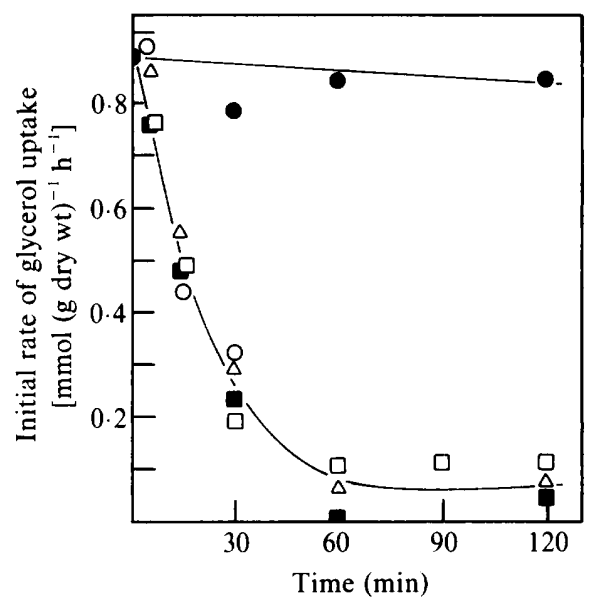

Fig. 1. Inactivation by glucose of the glycerol transport system in $F$. oxysporum var. lini. Initial uptake rates, $v$, of $5 \mathrm{~mm}-\left[{ }^{3} \mathrm{H}\right] \mathrm{glycerol}$ are shown. Control; $\bigcirc, 10 \mathrm{~mm}$-glucose; $\square, 20 \mathrm{mM} ; \triangle, 100 \mathrm{~mm}$ $300 \mathrm{~mm}$.

cells, in which saturation kinetics described the data without any diffusional component, in the concentration range used. A similar result was obtained for cells grown in the presence of glycerol plus glucose, indicating that synthesis of the glycerol transport system was repressed by glucose.

In ethanol-grown cells glycerol was transported with a $V_{\max }$ of $0.46 \pm 0.15 \mathrm{mmol}(\mathrm{g} \text { dry } \mathrm{wt})^{-1} \mathrm{~h}^{-1}(n=2)$, indicating that the transport system is partially constitutive.

Incubation of glycerol-grown cells with glucose resulted in a rapid decrease in the activity of the glycerol transport system, measured as the initial rate of uptake of $5 \mathrm{~mm}$-glycerol (Fig. 1). The rate of inactivation was independent of the glucose concentration in the range examined ( 10 to $300 \mathrm{mM}$ ). Lower concentrations were not suitable for the experiment, since a significant decrease in glucose concentration would occur due to assimilation by the fungus. After 10,30 and $60 \mathrm{~min}$, samples from the culture that had been incubated with $100 \mathrm{~mm}$-glucose were tested for reversibility of the process, by filtration and incubation in buffer without glucose for periods of 10 and $20 \mathrm{~min}$. Inactivation was irreversible (results not shown). 2-Deoxyglucose (50 mM) produced similar inactivation, while $50 \mathrm{~mm}$-6-deoxyglucose was ineffective.

\section{Enzyme activities and their regulation}

In order to gain an understanding of glycerol metabolism and enzyme regulation in $F$. oxysporum var. lini we measured the activities in cell extracts of enzymes that presumably were involved in glycerol metabolism in cells grown under different conditions (Table 2). Our results show that glycerol kinase and $\mathrm{NADP}^{+}$-glycerol dehydrogenase were constitutive while glycerol phosphate oxidase was only found when glycerol was the sole carbon source. NAD ${ }^{+}$-glycerol dehydrogenase or glycerol-3-phosphate dehydrogenase activities were not detected in extracts of cells grown under any conditions. The growth conditions had no effect on the specific activities of glycerol kinase or $\mathrm{NADP}^{+}$-glycerol dehydrogenase. 1,2-Propanediol, dihydroxyacetone and glyceraldehyde were phosphorylated in the assay of glycerol kinase activity in the crude extracts.

\section{Discussion}

Our results indicate that glycerol is transported in $F$. oxysporum var. lini by a facilitated diffusion transporter and that the synthesis of this system is under control of glucose repression and inactivation.

An interesting feature of the kinetics of the initial uptake of glycerol in $F$. oxysporum was that only saturable kinetics were observed for glycerol concentrations up to $10 \mathrm{~mm}$. Biphasic kinetics for glycerol transport have been reported in other micro-organisms. In Nocardia asteroides saturation kinetics was reported for concentrations up to $80 \mu \mathrm{M}$, although a linear 
component was detected at higher concentrations and interpreted as simple diffusion through the lipid bilayer (Calmes \& Deal, 1972). Uptake by simple diffusion was described for $S$. cerevisiae. In $C$. utilis no evidence for mediated transport was found although saturation kinetics were observed (Gancedo et al., 1968). These observations indicate differences in membrane lipid structure between $F$. oxysporum and the other microorganisms considered.

In spite of the importance in fungal physiology of glycerol as an osmoregulatory solute and in maintaining a proper anabolic reduction charge, no particular studies have focused on the transport system for glycerol. Mutants of $N$. crassa (Denor \& Courtright, 1982) and $A$. nidulans (Visser et al., 1988) unable to grow on glycerol have been isolated, and in both cases it was assumed that the mutation had occurred in genes for putative transporters. Since these mutations prevented growth it can be concluded that the plasma membranes of these fungi are also quite impermeable to glycerol.

In order to obtain evidence as to whether transporters accumulate solutes actively, measurement of the accumulation ratio of a nonmetabolizable analogue is a common procedure. A value of 1 for the accumulation ratio indicates that the transport system cannot accumulate the solute against a concentration gradient. 1,2 Propanediol was a competitive inhibitor of glycerol transport and an accumulation ratio of about 2 was obtained after uptake for $10 \mathrm{~min}$. CCCP had no effect. The fact that no counterflow was induced by the addition of an excess of glycerol can be explained by the presumed phosphorylation and hence trapping of 1,2-propanediol inside the cells. From the low value obtained for the accumulation ratio we presume that the system is not active. It is significant that in glucose-grown cells (which do not transport glycerol) the results were similar: the accumulation ratios were the same either when the analogue was transported by simple diffusion (in glucosegrown cells) or by facilitated transport (in glycerol-grown cells). Also, the fact that no $\mathrm{H}^{+}$uptake was observed during the initial uptake of glycerol supports the hypothesis that a $\mathrm{H}^{+}$-symporter is not involved. Movements of $\mathrm{K}^{+}$and $\mathrm{Na}^{+}$were also investigated using appropriate selective electrodes. No movements of these ions were associated with the initial uptake of glycerol (results not shown).

The glycerol transport system was rapidly inactivated by glucose. Inactivation was independent of the external sugar concentration in the range 10 to $300 \mathrm{~mm}$. This is probably an indication that metabolism of glucose is required in order for inactivation to occur. The highaffinity transporter for glucose is probably operating and is saturated in this concentration range (the halfsaturation constant for glucose is about $40 \mu \mathrm{M}$ ) (Brandão
\& Loureiro-Dias, 1990). Furthermore, inactivation was induced by glucose and 2-deoxyglucose but not by 6deoxyglucose, indicating that phosphorylation is probably involved in the inactivation process.

The metabolic pathway that we encountered in $F$. oxysporum is probably the most common among eukaryotic micro-organisms: glycerol is phosphorylated and then oxidized in the mitochondria by a flavindependent enzyme. It is significant that this last step is the only one (besides transport) which is regulated. Both the kinase and the NAD+-dependent glycerol dehydrogenase are probably involved in anabolic control of reducing power.

Our results indicate that the transport step is a main regulatory step in the utilization of glycerol by $F$. oxysporum var. lini. The system is certainly highly specific since only one competitive inhibitor was found. Mechanisms of regulation (e.g.) glucose repression and inactivation of the transporter and of the glycerol phosphate oxidase should be taken into consideration when the fungus is grown on complex substrates.

We thank Dr K. T. G. Ferreira for her excellent support in measuring intracellular volumes and Professor $\mathrm{N}$. van Uden for stimulating discussions and reading the manuscript.

I. M. C. was supported by a fellowship from CAPES, Ministério da Educação do Brasil.

\section{References}

AdLer, L. Blomberg, A. \& Nilsson, A. (1985). Glycerol metabolism and osmoregulation in the salt-tolerant yeast Debaryomyces hansenii. Journal of Bacteriology 162, 300-306.

ANDRE, L., Nilsson, A. \& ADLER, L. (1988). The role of glycerol in osmotolerance of the yeast Debaryomyces hansenii. Journal of General Microbiology 134, 669-677.

BRADFORD, M. M. (1976). A rapid and sensitive method for the quantitation of microgram quantities of protein utilizing the principle of protein-dye binding. Analytical Biochemistry 72, 248254.

BRandão, R. L. \& Loureiro-Dias, M. C. (1990). Regulation of sugar transport systems in Fusarium oxysporum var. lini. Applied and Environmental Microbiology 56, 2417-2420.

BURTON, R. M. (1955). Glycerol dehydrogenase from Aerobacter aerogenes. Methods in Enzymology 1, 397-400.

CAlmes, R. \& DEAL, S. J. (1972). Glycerol transport by Nocardia asteroides. Canadian Journal of Microbiology 18, 1703-1708.

COURTRIGHT, J. B. (1975). Intracellular localization and properties of glycerokinase and glycerophosphate dehydrogenase in Neurospora crassa. Archives of Biochemistry and Biophysics 167, 21-33.

Dawson, A. P. \& THORNE, C. J. R. (1975). L-3-Glycerophosphate dehydrogenase from pig brain mitochondria. Methods in Enzymology 41, 254-259.

DENOR, P. F. \& CoURTRIGHT, J. B. (1978). Isolation and characterization of glycerol-3-phosphate dehydrogenase-defective mutants of Neurospora crassa. Journal of Bacteriology 136, 960-968.

DENOR, P. F. \& CourTRIGHT, J. B. (1982). Genetic and enzymatic characterization of the inducible glycerol dissimilatory system of Neurospora crassa. Journal of Bacteriology 151, 912-917.

Ferreira, K. T. G. \& Swensson, W. M. (1979). The use of ${ }^{60} \mathrm{Co}-$ EDTA as an extracellular marker in frog skin. Biochimica et Biophysica Acta 552, 178-182. 
FlynN, T. G. \& CROMLISH, J. A. (1982). Glycerol dehydrogenase from rabbit muscle. Methods in Enzymology 89, 237-242.

Funayama, S., Gancedo, J. M. \& Gancedo, C. (1980). Turnover of yeast fructose-bisphosphatase in different metabolic conditions. European Journal of Biochemistry 109, 61-66.

GANCEDO, C., GANCEDO, J. M. \& Sols, A. (1968). Glycerol metabolism in yeasts. Pathways of utilization and production. European Journal of Biochemistry 5, 165-172.

GANCEDo, C., Llobell, A., Ribas, J.-C. \& LuCHI, F. (1986). Isolation and characterization of mutants from Schizosaccharomyces pombe defective in glycerol catabolism. European Journal of Biochemistry 159, 171-174.

Gartner, G. \& Kopperschlager, G. (1984). Purification and properties of glycerol dehydrogenase from Candida valida. Journal of General Microbiology 130, 3225-3233.

Jennings, D. H. (1984). Polyol metabolism in fungi. Advances in Microbial Physiology 25, 149-193.

JONES, L. R. \& RIDDICK, J. A. (1957). Colorimetric determination of 1,2-propanediol and related compounds. Analytical Chemistry 29, 1214-1216.

Kistler, W. S., Hirsch, C. A., Cozzarelli, N. R. \& Lin, E. C. C. (1969). Second pyridine nucleotide-independent $L-\alpha$-glycerophosphate dehydrogenase in Escherichia coli $\mathrm{K}-12$. Journal of Bacteriology 100, 1133-1135.

KistleR, W. S. \& Lin, E. C. C. (1972). Purification and properties of the flavine-stimulated anaerobic $L-\alpha$-glycerophosphate dehydrogenase of Escherichia coli. Journal of Bacteriology 112, 539-547.

KoCH, J. P., Hayashi, S. \& Lin, E. C. C. (1964). The control of dissimilation of glycerol and L- $\alpha$-glycerophosphate in Escherichia coli. Journal of Biological Chemistry 239, 3106-3108.
Kong, Y.-C., MaY, J. W. \& Marshall, J. H. (1985). Glycerol oxidation and triose reduction by pyridine nucleotide-linked enzymes in the fission yeast Schizosaccharomyces pombe. Journal of General Microbiology 131, 1571-1579.

Loureiro-Dias, M. C. \& Peinado, J. M. (1984). Transport of maltose in Saccharomyces cerevisiae. Effect of $\mathrm{pH}$ and potassium ions. Biochemical Journal 222, 293-298.

LuCAS, C., Costa, M. \& VAN UdEN, N. (1990). Osmoregulatory active sodium-glycerol co-transport in the halotolerant yeast Debaryomyces hansenii. Yeast 6, 187-191.

MaY, J. W. \& SLOAN, J. (1981). Glycerol utilization by Schizosaccharomyces pombe: dehydrogenation as the initial step. Journal of General Microbiology 123, 183-185.

NOBRE, M. F. \& COSTA, M. S. (1985). The accumulation of polyols by the yeast Debaryomyces hansenii in response to water stress. Canadian Journal of Microbiology 31, 1061-1064.

SANNo, Y., Wilson, T. H. \& LiN, E. C. C. (1968). Control of permeation to glycerol in cells of Escherichia coli. Biochemical and Biophysical Research Communications 32, 344-349.

Sweet, G., Gandor, C., Voegele, R., Wittekindt, N., Beuerle, J., TRUNIGER, V., LIN, E. C. C. \& Boos, W. (1990). Glycerol facilitator of Escherichia coli: cloning of $g l p F$ and identification of the $g l p F$ product. Journal of Bacteriology 172, 424-430.

VisSer, J., van Rooijen, R., DiJkema, C., Swart, K. \& Sealy-Lewis, H. M. (1988). Glycerol uptake mutants of the hyphal fungus Aspergillus nidulans. Journal of General Microbiology 134, 655-659.

WITteVeen, C. F. B., VAN De Vondervoort, P., DiJkema, C., SWART, K. \& VISSER, J. (1990). Characterization of a glycerol kinase mutant of Aspergillus niger. Journal of General Microbiology 136, 12991305. 